\title{
Analysis of Utterances by Older Persons in 'Life-Worldly' Communication with Caregivers in Japan
}

\author{
Yasuko Fukaya $^{1^{*}}$, Takanori Kitamura ${ }^{2}$, Sachiyo Koyama ${ }^{3}$, Kanako Yamakuma ${ }^{1}$ and Shinobu Sato ${ }^{4}$ \\ ${ }^{1}$ Kanto Gakuin University, Yokohama, Kanagawa, Japan \\ ${ }^{2}$ School of Law, Tokai University, Japan \\ ${ }^{3}$ Kitasato University, Japan \\ ${ }^{4}$ Dokkyo Medical University, Japan
}

*Corresponding author: Fukaya Y, Professor, Kanto Gakuin University, Nursing, 1-50-1 MutsuUra-Higashi Kanazawa-ku, Yokohama, Kanagawa 236-8503, Japan, Tel: 819088556969; E-mail: yafukaya@kanto-gakuin.ac.jp

Received date: July 24, 2016; Accepted date: October 17, 2016; Published date: October 25, 2016

Copyright: (C) 2016 Fukaya Y, et al. This is an open-access article distributed under the terms of the Creative Commons Attribution License, which permits unrestricted use, distribution, and reproduction in any medium, provided the original author and source are credited

\begin{abstract}
Objective: The purpose of this study is to grasp the actual conditions of utterances by elderly persons in geriatric care facilities in Japan. Specifically, the study considers utterance frequency, duration, and structure according to the two types of communication: Type I (Task-oriented) and Type II (Life-worldly).

Method: Study subjects were comprised of 37 residents in three long-term care facilities in Japan. The study surveyed the personal attributes of each elderly person, and the type and duration of utterances they made within 1 day. Type I and II communication characteristics were both quantitatively and qualitatively investigated.

Results: The duration of utterances from older residents was very short, at about 4 min. The average duration of utterances by elderly persons who are bedridden was $115.54 \mathrm{~s}(\mathrm{SD}=131.55)$, which was significantly lower $(p<0.05)$ in comparison to the average duration of utterances by elderly persons who are able to walk or move using a wheelchair, which was 331.1 s (SD=234.97). In type II communication, the utterances by the older resident were not limited to short replies to caregiver speech, but were relatively longer and self-initiated utterances were also produced.
\end{abstract}

Keywords: Communication; Elderly persons; Long term-care; Conversation analysis

\section{Introduction}

The number of older persons above the age of 65 requiring care in daily life due to illness or disability in Japan rose to 5,691,000 in 2013 [1]. Among them, $27.6 \%$ of older persons live in a care facility operated by the public insurance system (long-term care insurance system) [2].

Many older persons requiring care in Japan live their daily lives by receiving help from caregivers. For such older persons requiring care, communication plays an important role in building, maintaining and furthering relationships between older persons and their caregivers $[3,4]$. Particularly for older persons in geriatric care facilities, verbal communication is indispensable in establishing and maintaining selfidentity as a member of society [5] and exerts a strong influence on quality of life of older persons living a limited existence [6,7].

However, it has been noted in previous international studies regarding communication of older persons that, although those in nursing are aware of the importance of psychosocial communication, in practice they did not engage patients in social interaction [8]. It has also been noted that communication in geriatric care facilities contains little social interaction [9] and there is also a lack of verbal communication $[10,11]$. There are few opportunities for conversation [12], verbal communication is superficial and used by caregivers to control the older residents [13] and communication is limited and one- sided $[14,15]$. These problems with communication in geriatric facilities may be at least partly due to the fact that caregivers use communication with older persons as means for carrying out their duties.

In recent years, various studies using communication training programs for caregivers have been conducted to remedy some of the aforementioned communication issues in geriatric care facilities [16-18]. Many of these studies, however, focused on the improvements in the communication skills of caregivers rather than the older patients. Caris-Verhallen et al. [19] argues, based on a review of studies in the nurse-older person communication, that there is a lack of previous studies that take into consideration contributions made by the older to their communication. Thus, it is required to investigate the caregiver-older person communication as an "interaction" in which both parties interact with each other.

In Japan, however, there is little research regarding communication between caregivers and older persons living in care facilities, and even worse, verbal communication has not been clearly acknowledged as a care provision [3].

Therefore, we conducted a study [20] which demonstrated that verbal communication between caregivers and older residents of LongTerm Care Health Facilities falls into two types. The first type of communication is "task-oriented" communication, meaning communication for the purpose of performing various nursing or care tasks to facilitate the older residents' activities of daily living 
(henceforth "Type I" communication). The second type of communication is "life-worldly" communication (henceforth "Type II" communication), which encompasses verbal exchanges about family, work and social events that occur normally in social life. Analysis of the relationship between these two types of communication and utterances by older residents showed that Type II communication by caregivers elicited more utterances from older residents than did Type I communication.

The purpose of this study is to grasp the actual conditions of utterances by elderly persons in geriatric care facilities in Japan. Specifically, the study considers utterance frequency, duration, and structure according to the types of communication. We will thus focus specifically on older persons' self-initiated utterances as an indicator of communication similar to free daily conversation. For it has been argued that in an institutional settings (e.g. hospitals, courts and schools), in contrast to free-flowing ordinary conversation, communication is subject to various restrictions due to specific institutional arrangements, and thus users of the system (e.g. patients) tend not to be given opportunities to initiate conversation [21,22]. However, even in an institutional setting such as geriatric care facilities, Type II communication may have higher potential to develop into conversation close to ordinary conversation. In this type of conversation it is considered that there is an opportunity for free interactive conversation, in other words an opportunity for the older person to initiate communication.

Concurrently, with respect to the communicative ability of older persons, the effects of dementia level and the attributes of residents are noted [23] and thus, these must also be examined.

Furthermore, considering the fact that communication is essentially a mutual creation of both parties, we will also focus on the actual interaction between caregivers and older persons, and qualitatively analyze the structural mechanism of both Type I and Type II communication.

If these mechanisms could be made clear, it would be possible to encourage reconsideration of communication methods with nursing staff and future use for staff education.

Thus, the objective of this study is to examine: (a) the frequency and duration of all utterances and self-initiated utterances by older persons; (b) the relationship between the duration and frequency of utterances by older persons and their attributes; (c) the structural mechanism of older persons' utterances of Type I and Type II communication.

\section{Study Design and Methods}

This study uses a combination of two analysis methods: quantitative and qualitative. Quantitative method is concerned with objectives (a) and (b) above and qualitative method with objective (c) above.

\section{Definition of Terms}

Utterances: These comprise all speech by older residents, including utterances initiated by older persons and responses to speech initiated by caregivers. Utterances are categorized as the following task-oriented utterances and life-worldly utterances [20].

Task-oriented utterances (Type I utterances): Utterances by the older during communication with caregivers about various nursing and caregiver tasks to enable the residents' activities of daily living.
Life-worldly utterances (Type II utterances): Utterances by the older during communication with caregivers about family, work and social events that occur in normal social life.

Self-initiated utterances: Self-initiated utterances directed at another person, including both Type I and Type II communication.

A turn: An opportunity in which one person speaks at a time, which may consist of one or more components such as words, phrases, clauses and sentences [24].

\section{Subjects of the study}

The study surveyed the personal attributes of each elderly person, and the type and duration of utterances they made within 1 day.

The research target facility of this study is the Medical Long-Term Care Sanatorium, which is a facility for older persons who require care and higher medical needs due to chronic conditions. A total of 37 older residents live in three Medical Long-Term Care Sanatoriums

A total of 37 older residents in three geriatric care facilities in Prefecture A who matched the selection criteria below consented to cooperate with this study (10 from Facility A, 15 from Facility B and 12 from Facility $\mathrm{C}$ ). The basic attributes of the older subjects were: 11 men $(29.7 \%), 26$ women $(70.3 \%)$, ranging in age from $72-100$ years, with an average age of 84.6 years. The level of independence for performing activities of daily living (ADL) was comprised of 11 bedridden residents (29.7\%), 21 who used a wheelchair (56.8\%), 4 able to walk (10.8\%) and 1 unknown (2.7\%). Eight subjects (21.6\%) had verbal impairment and six persons (16.2\%) had auditory impairment. As defined by the classification of daily life independence for older persons with cognitive impairment in Japan's nursing-care insurance system, 5 subjects with no cognitive impairment (13.5\%), 1 subject (2.7\%) was classified I (cognitive impairment but able to live independently), 25 subjects (67.6\%) were II-III (cognitive impairment requiring partial nursing care), 5 (13.5\%) were IV (cognitive impairment requiring full-time nursing care) and one subject was unknown $(2.7 \%)$.

\section{Selection criteria for older subjects}

Selection criteria are:

1. Older persons 65 years and above requiring nursing care;

2. Older persons themselves or legal guardian able to provide written informed consent.

\section{Older person's exclusion criteria}

Exclusion criteria are:

1. Persons with total hearing loss;

2. Persons with total aphasia;

3. Persons with an unstable state of health

\section{Research period}

The research took place in November 2005.

\section{Research methods}

The observation period of the types and quantity of utterances by older residents lasted from 9:00 a.m. to 5:00 p.m. The observation involved an investigator assigned to one older subject, standing by in 
Citation: Fukaya Y, Kitamura T, Koyama S, Yamakuma K, Sato S (2016) Analysis of Utterances by Older Persons in 'Life-Worldly' Communication with Caregivers in Japan. J Nurs Care 5: 367. doi:10.4172/2167-1168.1000367

Page 3 of 10

the corridor outside the subject's room to avoid imposing a psychological burden, then accompanying the caregiver into the room when the caregiver entered and recording all conversation using a recording device, based on which a verbatim transcript was produced.

\section{Analysis Methods}

\section{Statistical analysis}

Classification of verbal communication type and measurement of frequency and duration of communication: To categorize the transcripts of the recorded conversation into communication types, we first coded each sentence from the transcripts. These codes were then assigned to the respective thirdly category, based on the 'Categories of Utterance by Older Persons', shown in Table 1. Three researchers assigned the codes for all the caregiver and older participants, with an agreement rate of $84 \%$ among the researchers. For the codes where they did not agree, the researchers categorized them after discussing their meaning within the conversational context. One sentence was calculated as having an utterance frequency of one for an individual category. Two syllables in the transcript were counted as one second in order to compare the utterance duration for each category (Table1).

\begin{tabular}{|c|c|c|c|}
\hline $\begin{array}{l}\text { Primary } \\
\text { Category }\end{array}$ & Secondary Category & Thirdly Category & Example \\
\hline \multirow[t]{23}{*}{ Type I } & Utterances related promotion of behavior & Acknowledge action instructions/urging & Yes, I understand. Um, that's OK. \\
\hline & & Confirm instruction/urged behavior & I'm supposed to take this medicine? \\
\hline & & Resist instruction/urged behavior & I'm coming now, so please wait! \\
\hline & & Indicate difficulty of instruction/urged behavior & If I sit, I can't remove my (socks). \\
\hline & & Refuse instruction/urged behavior & It's fine for now. Please do it later. \\
\hline & & Indicate action completion & I've finished. \\
\hline & Utterances related assistance behavior & Evaluate action and receive praise & $\begin{array}{l}\text { Thanks to you I was able to put it on by } \\
\text { myself. You were a big help. }\end{array}$ \\
\hline & & Acknowledge/reply to explanation of assistance action & Yes, I understand. \\
\hline & & Acknowledge/reply to assistance behavior start & Please do it for me. \\
\hline & & Acknowledge/reply to assistance behavior finish & Is it all done? Thank you. \\
\hline & & Evaluate assistance behavior & That felt good. \\
\hline & $\begin{array}{l}\text { Utterances about physical condition and daily } \\
\text { routine }\end{array}$ & $\begin{array}{l}\text { Acknowledge/reply to schedule explanation or } \\
\text { instruction }\end{array}$ & We are going to do it now, I understand. \\
\hline & & Ask question about schedule explanation/instruction & What time does (rehabilitation) start? \\
\hline & & Reply to question about completed daily schedule & I just finished rehabilitation. \\
\hline & & Receive evaluation of completed daily schedule & I still can't do it properly by myself. \\
\hline & & Reply to question about physical condition & That feels better. \\
\hline & & Acknowledge explanation about physical condition & That's why it hurt. \\
\hline & & Reply to confirming state of illness & It was bad until just a little while ago. \\
\hline & Confirming wishes and desires & Express will & Please turn on the television. \\
\hline & & Reply to confirming wish/desire & That's all right for now. \\
\hline & Warning to be careful & Acknowledge warning & I understand, I'Il be careful. \\
\hline & & Indicate difficulty in complying with warning & $\begin{array}{l}\text { It's difficult even if you warn me about it } \\
\text { because I'm going senile. }\end{array}$ \\
\hline & Other & & Ah, is that so? Uh-uh. \\
\hline \multirow[t]{2}{*}{ Type II } & Utterances about life experience & Talk about past experiences & $\begin{array}{l}\text { Long ago, we used to... I was best at } \\
\text { cooking... }\end{array}$ \\
\hline & & Talk about hobbies and tastes & $\begin{array}{l}\text { Ikebana is a hobby of mine.... I like sushi, I } \\
\text { often went with my husband.... }\end{array}$ \\
\hline
\end{tabular}


Citation: Fukaya Y, Kitamura T, Koyama S, Yamakuma K, Sato S (2016) Analysis of Utterances by Older Persons in 'Life-Worldly' Communication with Caregivers in Japan. J Nurs Care 5: 367. doi:10.4172/2167-1168.1000367

\begin{tabular}{|l|l|l|l|}
\hline & Talk about family, friends, acquaintances, pets & $\begin{array}{l}\text { We had a hard time with our son, but.... } \\
\text { Yesterday my grandchild came.... }\end{array}$ \\
\hline & Utterances about social events & Talk about social events & $\begin{array}{l}\text { The sumo yesterday.... The election's } \\
\text { coming up.... }\end{array}$ \\
\hline $\begin{array}{l}\text { Utterances about psychological state/ } \\
\text { knowledge }\end{array}$ & Talk about psychological state (emotions) & $\begin{array}{l}\text { I was lonely, but.... But thanks to you, today } \\
\text { I'm in good spirits. }\end{array}$ \\
\hline & Talk about knowledge or memory & $\begin{array}{l}\text { That's a chrysanthemum. Today's Culture } \\
\text { Day, isn't it? }\end{array}$ \\
\hline & Greetings & Good morning. \\
\hline & & $\begin{array}{l}\text { It's time for the plum trees to blossom, isn't } \\
\text { it? Isn't Miss XX here today? (Watching TV) } \\
\text { Haha, that's funny. }\end{array}$ \\
\hline
\end{tabular}

Table 1: Categories of utterances by older person, Note: Type I=Task-Oriented; Type II=Life-Worldly.

The study used a t-test to examine the relationship between the attributes of elderly persons and utterances they made. 37 of the study participants were used as subjects for analysis. We used SPSS Ver. 18 for the statistical analysis.

Conversation analysis: In conversation analysis, a detailed transcript was created from recordings of naturally occurring conversations, and the organization of the talk-in-interaction was examined [25]. In this study, we demonstrated how the utterance frequency of older residents changed in response to Type II speech through a comparison of the interactional characteristics of Type I and Type II communication.

\section{Ethical considerations}

The older residents and their representatives were given an oral explanation based on written material outlining the study objectives, methods, duration, expected benefits and disadvantages, and the guarantee of free will to participate or not participate in the study with no disadvantage incurred by deciding to not participate as well as a guarantee of privacy. Written informed consent to participate was then obtained through the free will of the participants. This study was approved by the Ethical Evaluation Committee.

\section{Results}

\section{Older person's utterance and self-initiated utterance}

As shown in Table 2, the duration of utterances over 1 day for each elderly person ranged from a minimum duration of $1 \mathrm{~s}$ to a maximum duration of $936.00 \mathrm{~s}$, with an average of 266.61 seconds $(\mathrm{SD}=228.73)$. The duration of Type I utterances ranged from a minimum duration of $1 \mathrm{~s}$ to a maximum duration of $630.50 \mathrm{~s}$, accounting for $66.50 \%$ of the total, with an average of $177.31 \mathrm{~s}(\mathrm{SD}=163.37)$. The duration of Type II utterances ranged from a minimum duration of $0 \mathrm{~s}$ to a maximum duration of $664 \mathrm{~s}$, with an average of $89.30 \mathrm{~s}(\mathrm{SD}=132.72)$. The average duration of Type I self-initiated utterances was 29.48 s $(\mathrm{SD}=41.30)$; these accounted for $16.60 \%$ of total Type I utterances. Meanwhile, the average duration of Type II self-initiated utterances was $21.62 \mathrm{~s}$ $(S D=29.34)$; these accounted for $24.20 \%$ of total Type II utterances.

\begin{tabular}{|c|c|c|c|c|c|c|c|c|c|c|c|}
\hline & \multirow[t]{2}{*}{$\mathbf{n}$} & \multicolumn{2}{|c|}{ Minimum } & \multicolumn{2}{|c|}{ Maximum } & \multicolumn{2}{|l|}{ M } & \multicolumn{2}{|l|}{ SD } & \multicolumn{2}{|l|}{$\%$} \\
\hline & & Second & Frequency & Second & Frequency & Second & Frequency & Second & Frequency & & \\
\hline Total utterance duration & 37 & 1 & & 936 & & 266.61 & & 228.73 & & 100 & \\
\hline Type I utterance duration & 37 & 1 & & 630.5 & & 177.31 & & 163.37 & & 66.5 & 100 \\
\hline Replied utterance & 37 & 0 & & 567 & & 147.82 & & 121.44 & & & 83.4 \\
\hline Self-initiated utterance & 37 & 0 & & 147.5 & & 29.48 & & 41.3 & & & 16.6 \\
\hline Type II utterance duration & 37 & 0 & & 664 & & 89.3 & & 132.72 & & 33.5 & 100 \\
\hline Replied utterance & 37 & 0 & & 559.5 & & 67.67 & & 118.79 & & & 75.8 \\
\hline Self-initiated utterance & 37 & 0 & & 104.5 & & 21.62 & & 29.34 & & & 24.2 \\
\hline Total utterance frequency & 37 & & 1 & & 311 & & 73.73 & & 56.63 & 100 & \\
\hline Type I utterance frequency & 37 & & 1 & & 290 & & 53.62 & & 49.43 & 72.7 & 100 \\
\hline Replied frequency & 37 & & 1 & & 275 & & 48.05 & & 46.42 & & 89.6 \\
\hline Self-initiated frequency & 37 & & 0 & & 23 & & 5.57 & & 6.5 & & 10.4 \\
\hline
\end{tabular}


Citation: Fukaya Y, Kitamura T, Koyama S, Yamakuma K, Sato S (2016) Analysis of Utterances by Older Persons in 'Life-Worldly' Communication with Caregivers in Japan. J Nurs Care 5: 367. doi:10.4172/2167-1168.1000367

Page 5 of 10

\begin{tabular}{|c|c|c|c|c|c|c|c|}
\hline Type II utterance frequency & 37 & 0 & 148 & 20.11 & 30.53 & 27.3 & 100 \\
\hline Replied frequency & 37 & 0 & 141 & 16.59 & 28.18 & & 82.5 \\
\hline Self-initiated frequency & 37 & 0 & 16 & 3.51 & 4.44 & & 17.5 \\
\hline
\end{tabular}

Table 2: Descriptive statistics about utterance duration and frequency, Note: Type I utterance=Task-oriented utterances; Type II utterance=Lifeworldly utterances; $\mathrm{SD}=$ Standard Deviation.

The frequency of utterances over 1 day for each elderly person ranged from a minimum frequency of 1 time to a maximum frequency of 311.00 times, with an average of 73.77 times $(\mathrm{SD}=56.63)$

\section{Relationships between duration of older persons' utterance and attributes}

We investigated whether the attributes (ADL, auditory disorders, language disorders and dementia) of the older residents influenced the duration of their utterances.

As shown in Table 3, the average duration of utterances by elderly persons who are bedridden was $115.54 \mathrm{~s}(\mathrm{SD}=131.55)$, which is significantly lower in comparison to the average duration of utterances by elderly persons who are able to walk or to move using a wheelchair which was $337.10 \mathrm{~s}(\mathrm{SD}=234.97)$. No significant differences were observed with regard to the presence or absence of auditory disorders, language disorders or dementia. However, the average duration of utterances by elderly persons without language disorders was $299.95 \mathrm{~s}$ $(\mathrm{SD}=230.74)$, which is around double the average duration of utterances by elderly persons with language disorders at $145.75 \mathrm{~s}$ $(\mathrm{SD}=186.59)$. The average frequency of utterances by elderly persons who are bedridden was 40.27 occurrences ( $\mathrm{SD}=28.78)$, which is significantly lower in comparison to the average frequency of utterances by elderly persons who are able to walk or to move using a wheelchair which was 88.88 occurrences $(\mathrm{SD}=60.9)$.

\begin{tabular}{|c|c|c|c|c|c|c|c|c|c|c|}
\hline \multirow{3}{*}{$\begin{array}{l}\begin{array}{l}\text { Older person's } \\
\text { utterance }\end{array} \\
\begin{array}{l}\text { Utterance } \\
\text { duration }\end{array}\end{array}$} & \multirow{2}{*}{\multicolumn{2}{|c|}{ Attributes }} & \multirow{3}{*}{$\begin{array}{l}\mathbf{n} \\
11\end{array}$} & \multicolumn{2}{|l|}{$M$} & \multicolumn{2}{|l|}{ SD } & \multirow{3}{*}{$\begin{array}{l}\mathbf{F} \\
4.56\end{array}$} & \multirow{3}{*}{\begin{tabular}{|l|}
$\mathbf{t}$ \\
-3.6 \\
\end{tabular}} & \multirow{3}{*}{ * } \\
\hline & & & & \multirow{2}{*}{\begin{tabular}{|l|} 
Second \\
115.54 \\
\end{tabular}} & \multirow[t]{2}{*}{ Frequency } & \multirow{2}{*}{$\begin{array}{l}\text { Second } \\
131.55\end{array}$} & \multirow[t]{2}{*}{ Frequency } & & & \\
\hline & $\mathrm{ADL}$ & bedridden & & & & & & & & \\
\hline & & walk/wheelchair & 25 & 337.1 & & 234.97 & & & & \\
\hline & $\begin{array}{l}\text { auditory } \\
\text { disorders }\end{array}$ & no & 31 & 262.97 & & 238.27 & & 1.01 & -0.22 & ns \\
\hline & & yes & 6 & 285.42 & & 188.55 & & & & \\
\hline & $\begin{array}{l}\text { language } \\
\text { disorders }\end{array}$ & no & 29 & 299.95 & & 230.74 & & 0.75 & 1.73 & ns \\
\hline & & yes & 8 & 145.75 & & 186.59 & & & & \\
\hline & dementia & no & 6 & 279.33 & & 175.6 & & 1.2 & 0.1 & ns \\
\hline & & yes & 30 & 269.22 & & 242.41 & & & & \\
\hline \multirow{7}{*}{$\begin{array}{l}\text { Utterance } \\
\text { frequency }\end{array}$} & ADL & bedridden & 11 & & 40.27 & & 28.78 & 2.5 & -2.51 & * \\
\hline & & walk/wheelchair & 25 & & 88.88 & & 60.9 & & & \\
\hline & $\begin{array}{l}\text { auditory } \\
\text { disorders }\end{array}$ & no & 31 & & 71.35 & & 60.91 & 1.74 & -0.57 & ns \\
\hline & & yes & 6 & & 86 & & 24.83 & & & \\
\hline & $\begin{array}{l}\text { language } \\
\text { disorders }\end{array}$ & no & 29 & & 80.07 & & 58.09 & 0.02 & 1.31 & ns \\
\hline & & yes & 8 & & 50.75 & & 47.17 & & & \\
\hline & dementia & no & 6 & & 57.33 & & 36.62 & 0.68 & -0.77 & ns \\
\hline
\end{tabular}


Citation: Fukaya Y, Kitamura T, Koyama S, Yamakuma K, Sato S (2016) Analysis of Utterances by Older Persons in 'Life-Worldly' Communication with Caregivers in Japan. J Nurs Care 5: 367. doi:10.4172/2167-1168.1000367

Page 6 of 10

\begin{tabular}{|l|l|l|l|l|l|l|l|l|l|l|}
\hline & yes & 30 & & 77.23 & 60.67 & & & \\
\hline
\end{tabular}

Table 3: Relationship between an elderly person's personal attributes and the duration and frequency, Note: SD=Standard Deviation; ${ }^{\star}<0.05$, ${ }^{* *}<0.001$; ns $=$ Not statistically significant.

Table 4 shows the relationship between an elderly person's personal attributes and the duration and frequency of their self-initiated utterances. The average duration of utterances by elderly persons who are bedridden was $20.86 \mathrm{~s}(\mathrm{SD}=37.31)$; the average duration of utterances by elderly persons who are able to walk or to move using a wheelchair was around triple this, at $61.96 \mathrm{~s}(\mathrm{SD}=55.65)$. The average frequency of self-initiated utterances by elderly persons who are bedridden was 3.54 occurrences; the average frequency of utterances by elderly persons who are able to walk or to move using a wheelchair was around triple this, at $11.48 \mathrm{~s}(\mathrm{SD}=8.37)$. No significant differences were observed with regards to the presence or absence of auditory disorders, language disorders or dementia.

\begin{tabular}{|c|c|c|c|c|c|c|c|c|c|c|}
\hline \multirow{2}{*}{ Older person's utterance } & \multirow{2}{*}{\multicolumn{2}{|c|}{ Attributes }} & \multirow{2}{*}{$\mathbf{n}$} & \multicolumn{2}{|l|}{ M } & \multicolumn{2}{|l|}{ SD } & \multirow[t]{2}{*}{$\mathbf{F}$} & \multirow[t]{2}{*}{$\mathrm{t}$} & \multirow[t]{2}{*}{$\mathbf{p}$} \\
\hline & & & & Second & Frequency & Second & Frequency & & & \\
\hline \multirow[t]{8}{*}{$\begin{array}{l}\text { Duration of self-initiated } \\
\text { utterances }\end{array}$} & $\mathrm{ADL}$ & bedridden & 11 & 20.86 & & 37.31 & & 2.24 & -2.22 & * \\
\hline & & walk/wheelchair & 25 & 61.96 & & 55.65 & & & & \\
\hline & $\begin{array}{l}\text { auditory } \\
\text { disorders }\end{array}$ & no & 31 & 54.82 & & 57.29 & & 4.24 & 1.49 & ns \\
\hline & & yes & 6 & 31.91 & & 28.98 & & & & \\
\hline & $\begin{array}{l}\text { language } \\
\text { disorders }\end{array}$ & no & 29 & 58.05 & & 54.04 & & 0.44 & 1.51 & ns \\
\hline & & yes & 8 & 25.94 & & 40 & & & & \\
\hline & dementia & no & 6 & 83.58 & & 65.93 & & 0.8 & 1.59 & ns \\
\hline & & yes & 30 & 45.68 & & 50.88 & & & & \\
\hline \multirow[t]{8}{*}{$\begin{array}{l}\text { Frequency of self-initiated } \\
\text { utterances }\end{array}$} & $\mathrm{ADL}$ & bedridden & 11 & & 3.54 & & 5.26 & 3.55 & -2.89 & * \\
\hline & & walk/wheelchair & 25 & & 11.48 & & 8.37 & & & \\
\hline & $\begin{array}{l}\text { auditory } \\
\text { disorders }\end{array}$ & no & 31 & & 9.29 & & 8.66 & 1.6 & 0.35 & ns \\
\hline & & yes & 6 & & 8 & & 6 & & & \\
\hline & $\begin{array}{l}\text { language } \\
\text { disorders }\end{array}$ & no & 29 & & 10.06 & & 7.93 & 0.12 & 1.41 & ns \\
\hline & & yes & 8 & & 5.5 & & 8.86 & & & \\
\hline & dementia & no & 6 & & 12.5 & & 9.35 & 0 & 1.06 & $\mathrm{~ns}$ \\
\hline & & yes & 30 & & 8.57 & & 8.09 & & & \\
\hline
\end{tabular}

Table 4: Relationships between duration of older persons' utterance and frequency and attributes, Note: SD=Standard Deviation; ${ }^{*}<0.05,{ }^{* *}<0.001$; ns=Not statistically significant.

The relation between the degree of ADL and the other attributes of elderly persons was considered because the average duration and frequency of utterances at the bedridden older persons were significantly lower than those of elderly persons who can walk or move with a wheelchair. The significant relation between the degree of ADL and auditory disorders, language disorders and dementia was not observed.

\section{Conversation analysis results}

\section{Type I utterances and their communication context}

Excerpt 1 in Table 5, taken from a bed-bath assistance scene, is an example of where Type I communication is observed (Table 5). 
Citation: Fukaya Y, Kitamura T, Koyama S, Yamakuma K, Sato S (2016) Analysis of Utterances by Older Persons in 'Life-Worldly' Communication with Caregivers in Japan. J Nurs Care 5: 367. doi:10.4172/2167-1168.1000367

Page 7 of 10

\begin{tabular}{|c|c|c|c|c|c|}
\hline \multicolumn{3}{|c|}{ Excerpt 1 (Type I) } & \multicolumn{3}{|c|}{ Excerpt 2 (Type II) } \\
\hline 1 & CP: & $\begin{array}{l}\text { Sukoshi senakawo fukimasu. } \\
\text { l'll wipe your back a bit. }\end{array}$ & 1 & CP1: & $\begin{array}{l}\text { Sato-imo wa mada desu ka? } \\
\text { Taro aren't ready yet?= }\end{array}$ \\
\hline 2 & OP: & $\begin{array}{l}\text { Hai. } \\
\text { Yes. }\end{array}$ & 2 & OP: & $\begin{array}{l}=\text { korekara desu } \\
=\text { Just about to be. }\end{array}$ \\
\hline 3 & CP: & $\begin{array}{l}\text { li? Yoko mukemasuka? } \\
\text { OK? Can you turn to the side? }\end{array}$ & 3 & & $(0.2)$ \\
\hline 4 & OP: & $\begin{array}{l}\text { nn, sonomama ni shite. } \\
\text { No, leave me as I am. }\end{array}$ & 4 & CP1: & $\begin{array}{l}\text { Un } \\
\text { Yeah }\end{array}$ \\
\hline 5 & CP: & $\begin{array}{l}\text { Hhh. Senaka wo fukimasu-kara, yokowomui-te. } \\
\text { Hhh. l'll wipe your back, so let's turn to the side. }\end{array}$ & 5 & & $(0.4)$ \\
\hline 6 & OP: & $\begin{array}{l}\text { Uhuh } \\
\text { Uhuh }\end{array}$ & 6 & OP: & $\begin{array}{l}\text { Kotoshi wa dekita kana to omotte } \\
\text { I was wondering if they're ready this year }\end{array}$ \\
\hline 7 & CP: & $\begin{array}{l}\text { ii-desuka? Hai. Sokoni tukamatte kudasai. } \\
\text { OK? Yeah. Just hold onto it please. }\end{array}$ & 7 & CP2: & $\begin{array}{l}\text { Huhuhuhu hu } \\
\text { Huhuhuhu hu }\end{array}$ \\
\hline 8 & & $(0.5)$ & 8 & OP: & $\begin{array}{l}\text { amega yoku futta kara } \\
\text { Because a lot of rain fell. }\end{array}$ \\
\hline 9 & CP: & $\begin{array}{l}\text { Tukamatte. } \\
\text { Ho:Id onto it. }\end{array}$ & 9 & CP2: & $\begin{array}{l}\text { soudane ame futta monone? } \\
\text { That's right:: There was a lot of rain, wasn't there::? }\end{array}$ \\
\hline 10 & & $(0.5)$ & 10 & OP: & $\begin{array}{l}\text { Uchino musukowa imane, Kinoko-tori ni muchuu= } \\
\text { My son is now engrossed in picking mushrooms= }\end{array}$ \\
\hline 11 & CP: & $\begin{array}{l}\text { Konna funi? } \\
\text { Like this? }\end{array}$ & 11 & CP2: & $\begin{array}{l}=\text { Ahahahahahaha kinoko ka::? } \\
=\text { Ahahahahahaha mushrooms? Haha:: }\end{array}$ \\
\hline 12 & & $(1.0)$ & 12 & OP: & $\begin{array}{l}\text { Kinoko wo torini }= \\
\text { Going picking mushrooms }=\end{array}$ \\
\hline 13 & CP: & $\begin{array}{l}\text { Dokoka kayu-toko arimasu-ka? Senaka-wa? } \\
\text { Anywhere itchy? On your back? }\end{array}$ & 13 & CO2: & $\begin{array}{l}=\text { aa sounano? Mou osoinn-jya naino? } \\
=\text { Is that so? Isn't it too late? }\end{array}$ \\
\hline 14 & & (2.5) & 14 & OP: & $\begin{array}{l}\text { Nani? } \\
\text { What? }\end{array}$ \\
\hline 15 & CP: & $\begin{array}{l}\text { Dokomo? } \\
\text { Nowhe:re? }\end{array}$ & 15 & CP1: & $\begin{array}{l}\text { Ima jikinano? (0.3) mou osoinn-jya naino? } \\
\text { Is it the season now? }(0.3) \text { Is it just right? Now? }\end{array}$ \\
\hline 16 & OP: & $\begin{array}{l}\text { Ee. Ano: } \\
\text { No. Well: }\end{array}$ & 16 & OP: & $\begin{array}{l}\text { Ima, chodo-ii jikidesu. } \\
\text { Now is just the right time. }\end{array}$ \\
\hline 17 & CP: & $\begin{array}{l}\text { Hai? } \\
\text { Yes? }\end{array}$ & 17 & CP1: & $\begin{array}{l}\text { Nn: (0.8) hahaha } \\
\text { Mm: (0.8) hahaha }\end{array}$ \\
\hline 18 & & $(1.2)$ & 18 & OP: & $\begin{array}{l}\text { Kama wo oite kichattande, } \\
\text { He left the little sickle when he came, }\end{array}$ \\
\hline 19 & CP: & $\begin{array}{l}\text { Omutu-no mawari wa? Sokowa daijyoubu desuka? } \\
\text { What about around your diaper? Are you OK around there? }\end{array}$ & 19 & CP1: & $\begin{array}{l}\text { E? } \\
\text { What? }\end{array}$ \\
\hline 20 & OP: & $\begin{array}{l}\text { Hai. } \\
\text { Yes. }\end{array}$ & 20 & OP: & $\begin{array}{l}\text { Kama wo ne. } \\
\text { The little sickle. }\end{array}$ \\
\hline 21 & & $((5$ lines omitted $))$ & 21 & CP1: & $\begin{array}{l}\mathrm{Nn}: \\
\mathrm{Mm}:\end{array}$ \\
\hline 22 & & $(8.0)$ & 22 & OP: & $\begin{array}{l}\text { Kamawo ne, yamani oiteccha-tten desu. } \\
\text { The little sickle, he left it on the mountain. }\end{array}$ \\
\hline \multirow[t]{2}{*}{23} & CP: & $\begin{array}{l}\text { OK, owari-mashita. Hai, saa iidesuyo. } \\
\text { OK, finished. Yes, it's OK. Please let go. }\end{array}$ & 23 & CP1: & $\begin{array}{l}\text { Nn: (2.0) kinoko ni kuwashii-in desukaka, musuko-san wa? } \\
\text { Ah: (2.0) He's knowlegeable about mushrooms is he, your son? }\end{array}$ \\
\hline & & & 24 & OP: & Hon wo katte yonnderu no. \\
\hline
\end{tabular}




\begin{tabular}{|l|l|l|l|l|l|}
\hline & & & & He's reading a book he bought about it. \\
\hline & & 25 & CP1: & $\begin{array}{l}\text { Ah: sou:? (0.4) hee: } \\
\text { Is that so: ? (0.4) Wow: }\end{array}$ \\
\hline
\end{tabular}

Table 5: Examples of Type I and II communication, Note: For transcription conventions, see Heritage \& Maynard [25], CP=Care Providers. $\mathrm{OP}=$ Older Person. Every line contains Japanese utterances and their English translation.

Characteristics of turn taking and self-initiated utterance: All the caregiver's speaking turns, in lines $1,3,5,7,9,11,13,15,17,19$ and 23 , are started on her own initiative, as questions, urgings or requests, leading and controlling the conversation. In contrast, all the utterances of the resident, in lines 2, 4, 6, 16 and 20, are all replies to what the caregiver said. In other words, the older persons' utterances are all produced as urged responses prompted by the caregiver's speech. Thus, self-initiated utterances by the resident are entirely absent.

Characteristics of conversation content: The content of the caregiver speech prepares the older resident by urging them to cooperate with a specific nursing task, such as wiping the resident's back (lines $1,3,5,7$, $9,11,1315,17,19$ and 23). In other words, the caregiver selects a topic that is, content, of conversation (a nursing task), by initiating conversational sequences with the view to achieving that specific nursing task. In response, the resident gives a confirming response or complies with what the caregiver urges them to do (lines 2 and 20). When a disconfirming response is given (lines 4,8 and 10), the caregiver urges compliance (lines 7 to 9). As a result, the content of conversation is confined to the specific nursing task that the caregiver desires to implement and the older persons' responses concerning that nursing task.

Characteristics of utterance length: Notice that the length of caregiver speech is usually longer (lines $1,3,5,7-11,13-14$ ). In contrast, the utterances by older persons are in most circumstances of minimal length (lines 2, 6, 12 and 15). The reason is that the caregiver speech initiates and leads the communication, thereby restricting conversational content to the specific nursing tasks and as a result, places restraints on what the resident should say or do in the next speaking turns, with the result that the resident is given almost no opportunities for self-initiated utterances and only produces short replies and complies with the caregiver's requests or urgings.

\section{Type II utterances and their communication context}

Excerpt 2 in Table 5 is an example of a conversation displaying Type II utterances.

Characteristics of turn taking and self-initiated utterance: The conversation is started when, in line 1 , the caregiver asks a question about 'taro' (coco-yam). In response to this question, the resident produces a reply in line 2. Caregiver 1 acknowledges this reply with a brief acknowledgement token which, together with a short silence of $0.4 \mathrm{~s}$, indicates that she will not speak further. This gives the older resident the opportunity to take a turn-at-talk. The older resident thus begins to speak on her own initiative in line 6 and to further expand her utterance from line 8 to lines 10,12, 18, 20 and 22. In other words, the older resident is treated as the "story-teller" and given the opportunity to elaborate on and develop her story by producing selfinitiated utterances.

Characteristics of conversation content: Caregiver proffers a topic ("taro") by asking a question of the older (line 1). This topic pertains to the life-world of the older resident. As is evident from its grammatical construction (i.e., an interrogative), this speech presupposes that the caregiver has no or less knowledge about this topic, and thus it is the resident who has the right and authority to talk about it.

Characteristics of utterance length: In Excerpt 2, utterances by the older resident are not limited to short replies to caregiver speech, but are relatively longer, and self-initiated utterances are also produced (lines $6,8,10,14-22$ ). The reason is that Type II communication is closer to ordinary conversation and when the residents are provided a topic pertaining to their life-world, they had more opportunities to initiate their own speech and develop their story as the "story-teller". The resident's utterances are upheld by caregiver's discursive support such as acknowledgements and expressions of agreement (line 4, 9 and $21)$, the caregivers' laughter (line 7,17 ) and expressions of strong interest (lines 11,13 and 25) (Table 5).

\section{Discussion}

\section{Characteristics of type I utterances by older persons}

The daily duration of utterances from older residents was very short, at about $4 \mathrm{~min}$. One factor in the shortness of utterance duration was the characteristic of Type I communication accounting for $66.5 \%$ of total utterances. Type I communication is conversation associated with completing nursing and care tasks to support the activities of daily life of the older residents, and therefore caregivers direct the conversation. In this context, the conversation topics are limited to those raised and initiated by the caregivers, and since almost all utterances by the older are restricted to replies in an order determined by their caregivers, they tend to be very short, which creates an environment wherein it is difficult for the older to produce self-initiated utterances.

Such restricted conversation is seen widely in medical settings, and Jones and Collins [26] revealed through analysis of actual conversations in admission interviews that topics proposed by patients are not followed up on or given assessment, which severely restricts what patients can contribute to the consultation. However, Kaakinen [27] pointed out that conversational quantity was limited due to the communication rules and self-restraint exercised by residents to avoid causing trouble when conversing with others in order to adapt to the environment of the nursing home. We therefore infer that self-restraint by residents themselves is also a factor limiting the duration and frequency of older persons' utterances.

Chatwin et al. [28] found that even in this type of restricted communication, if ordinary short conversation is included in medical interviews, the doctor-patient relationship becomes more interactive and builds rapport. Thus, even within Type I communication that is inherently highly task-oriented, combining it with Type II communication, which on the surface appears unrelated to completing medical or nursing tasks, has the potential to develop better two-way communication. 


\section{Characteristics of type II utterances by older persons}

Previously identified problems in caregiving for older persons include circumstances in which patients want to continue interactions with social talk, but nurses want to hurry up [29] and the belief of residents in geriatric facilities that they are not given the opportunity to speak [12]. Krause and Rook [30] pointed out that such a lack of mutual interaction between caregivers and older persons causes chronic stress in the older persons. However, as was shown in this research, if the older persons are properly given opportunities to speak, they will likely be able to pursue more conversation about their own life-world, as seen in the previously-mentioned Excerpt 2. In Type II communication where free conversation like ordinary daily conversation such as this develops, increased two-way communication was observed.

The reason for this was that the older were given the possibility of expanded utterance opportunities and self-initiated utterances when nursing caregivers presented these life-worldly topics to older residents as topics that the residents should talk about, response by nursing caregivers exhibited strong approval and interest, and indicated caregivers were listening attentively. Heliker [31] speaks of the importance of story-sharing and conversation between caregivers and older residents of long-term care facilities, as the older use stories to give shape to the course of their lives up to that point through the spoken word. In the past, although nursing caregivers were aware of the importance of psychosocial communication, it has been noted that in reality nurses had little priority for communicating with patients [32]. However, in limited living spaces, relationships with a limited number of people, and during the final stages of their lives, more affective and/or socio-emotional communication between older residents and facility caregivers is needed.

\section{The relationship between the personal attributes of each elderly person and the duration of their utterances}

In terms of the relationship between the personal attributes of each elderly person and the duration and frequency of their utterances, the duration and frequency of utterances by bedridden patients was significantly less than those by elderly persons who are able to move using a wheelchair or by walking. For this reason, the relationship between being bedridden and language disorder was examined, but no significant relationship was found. The relationship between communication by nursing staff and the personal attributes of elderly persons in geriatric care facilities was examined in previous study [33]; the study revealed that staff communicated twice as frequently with bedridden elderly persons as with other elderly persons. However, the majority of these communications was Type I, i.e., encouragement of daily activities and explanations of care procedures. The lack of utterances by bedridden elderly persons in this study is considered to be a limitation due to one-way communication, where no response was expected from such elderly persons.

\section{The Limitation and Challenges of this Study}

The number of facilities that approved study for this research was only three and very few. Also, it was extremely difficult to secure research subjects that met the selection standard of older persons for this study as most of the older persons living in Medical Long-Term Care Sanatoriums suffer from severe cases of dementia. For this reason, the number of subjects in this study was 37 and very few, and thus there is the possibility of Type I error being included in the analysis result. In the future it is necessary to increase the number of samples and further clarify the current state of communication between staff and older persons.

\section{References}

1. Japan Ministry of Health, Labour and Welfare (2015, August 30) Nursing Insurance Industry Status report, 2013.

2. Cabinet Office, Government of Japan (2015, August 30) Index of Older persons requiring care.

3. Littlejohn SW (1999) Theories of human communication. Beverly Hills, Sage Publications, CA.

4. Balzer-Riley J (2004) Communication in nursing, St. Louis, Mosby, Missouri.

5. Sigman SJ (1985) Conversational behavior in two health care institutions for the elderly. Int J Aging Hum Dev 21: 137-154.

6. Kane RA (2001) Long-term care and a good quality of life: bringing them closer together. Gerontologist 41: 293-304.

7. Armstrong-Esther CA (1994) Long-term care reform in Alberta, Canada: The role of the resident classification system. J Adv Nurs 19: 105-113.

8. Levy-Storms L (2008) Therapeutic communication training in long-term care institutions: Recommendations for future research. Patient Educ Couns 73: 8-21.

9. Grau L, Chandler B, Saunders C (1995) Nursing home residents' perceptions of the quality of their care. J Psychosoc Nurs Ment Health Serv 33: 34-41.

10. Burgio LD, Allen-Burge R, Roth DL, Bourgeois MS, Dijkstra K, et al. (2001) Come talk with me: Improving communication between nursing assistants and nursing home residents during care routines. Gerontologist 41: 449-460.

11. Nussbaum JF (1993) The communicative impact of institutionalization for the elderly: The admissions process. Journal of Aging Studies 11: $149-165$.

12. Liukkonen A (1995) Life in a nursing home for the frail elderly: Daily routines. Clin Nurs Res 4: 358-370.

13. Hewison A (1995) Nurses' power in interactions with patients. J Adv Nurs 21: $75-82$.

14. Gibb H, O'Brien B (1990) Jokes and reassurance are not enough: Ways in which nurses relate through conversation with elderly clients. J Adv Nurs 15: $1389-1401$.

15. Nussbaum JF (1991) Communication, language and the institutionalized elderly. Aging and Society 11: 149-165.

16. Roth DL, Stevens AB, Burgio LD, Burgio KL (2002) Timed-event sequential analysis of agitation in nursing home residents during personal care interactions with nursing assistants. J Gerontol B Psychol Sci Soc Sci 57: P461-468.

17. Williams K, Kemper S, Hummert ML (2003) Improving nursing home communication: An intervention to reduce elder speak. Gerontologist 43: 242-247.

18. MacGilton K, Irwin-Robinson H, Boscart V, Spanjevic L (2006) Communication enhancement: Nurse and patient satisfaction outcomes in complex continuing care facilities. Journal of Advanced Nursing 54: 35-44.

19. Caris-Verhallen, WMGM, Kerksta A, Bensing JM (1997) The role of communication in nursing care for older persons: A review of literature. Journal of Advanced Nursing 25: 915-933.

20. Fukaya Y, Suzuki K, Shitita K (2004) Predictors and correlates of frequency and the length of verbal communications between nursing staff and elderly residents in geriatric care facilities. Japan Journal of Nursing Science 1: 107-115.

21. Psathas G (1995) Conversation analysis: The study of talk-in-interaction. Thousand Oaks, Sage Publications, CA.

22. Drew P, Heritage J (1992) Analyzing talk at work: An introduction. In P. Drew and J. Heritage (Eds.), Talk at work: Interaction in institutional settings, Cambridge University Press, New York. 
Citation: Fukaya Y, Kitamura T, Koyama S, Yamakuma K, Sato S (2016) Analysis of Utterances by Older Persons in 'Life-Worldly' Communication with Caregivers in Japan. J Nurs Care 5: 367. doi:10.4172/2167-1168.1000367

Page 10 of 10

23. Bayles KA, Tomoeda CK (1991) Caregiver report on the prevalence and appearance order of linguistic symptoms in Alzheimer's patients. The Gerontologist 31: 206-210.

24. Sacks H, Schegloff EA, Jefferson G (1974) The simplest systematic for the organization of turn-taking for conversation. Language 50: 696-735.

25. Heritage J, Maynard DW (2006) Communication in medical care Interaction between primary care physicians and patients. Cambridge University Press, Cambridge.

26. Jones A, Collins S (2007) Nursing assessments and other tasks: Influences on participation in interactions between patients and nurses. In $\mathrm{S}$. Collins, N. Britten, J. Ruusuvuori, A.Thompson (eds..) Patient participation in health care consultations: Qualitative Perspectives, Open University Press, McGraw-Hill, Berkshire.

27. Kaakinen JR (1992) Living with silence. Gerontologist 32: 258-264.

28. Chatwin J, Collins S, Watt I, Field R (2007) A feeling of equality: Some interactional features that build rapport and mutuality in a therapeutic encounter. In S. Collins, N. Britten, J. Ruusuvuori, A Thompson (eds.,)
Patient participation in health care consultations: Qualitative perspectives, Open University Press, New York.

29. Le May AC, Redferm SJ (1987) A study of non-verbal communication between nurses and elderly patients. Research in the Nursing Care of Elderly People, John Wiley and Sons Ltd., Chichester.

30. Krause N, Rook KS (2003) Negative interaction in late life: Issues in the stability and generalizability of conflict across relationships. J Gerontol B Psychol Sci Soc Sci 58: P88-99.

31. Heliker D (2007) Story sharing: restoring the reciprocity of caring in long-term care. J Psychosoc Nurs Ment Health Serv 45: 20-23.

32. Nolan M, Grant G, Noran J (1995) Busy doing nothing: Activity and interaction levels amongst Differing populations of elderly patients, Journal of advanced Nursing 22: 528-538

33. Fukaya Y, Koyama S, Kimura Y, Kitamura T (2009) Education to promote verbal communication by caregivers in geriatric care facilities. Jpn J Nurs Sci 6: 91-103. 